\title{
Gangguan Metabolik pada Leukemia Limfositik Akut dengan Hiperleukositosis
}

\author{
Endang Windiastuti, Caroline Mulawi
}

\begin{abstract}
Salah satu kegawatan onkologi adalah hiperleukositosis, yang ditandai dengan meningkatnya jumlah leukosit darah perifer lebih dari 100000 per ul. Hiperleukositosis dapat ditemukan pada 6-15\% kasus leukemia limfositik akut, 13-22\% kasus leukemia non-limfositik akut dan pada hampir semua kasus mielogenus kronis. Komplikasi akan timbul apabila keadaan ini tidak ditangani segera, seperti perdarahan intrakranial, perdarahan pulmonal, serta gangguan metabolik akibat lisis dari sel leukemia. Gangguan metabolik yang mengikuti keadaan tumor lysis syndrom ini berupa hiperurisemia, hiperkalemia, hiperfosfatemia dan hipokalsemia sekunder, serta kadang-kadang ditemukan asidosis laktat. Di Bagian IKA FKUI/RSCM Jakarta terdapat 57 (22\%) pasien LLA dengan hiperleukositosis dan gangguan metabolik yang paling menonjol ialah hiperurikemia $(38,5 \%)$ dan asidosis laktat (46\%). Untuk mengatasi gangguan metabolik pada hiperleukositosis dilakukan hidrasi dan alkalinisasi, serta pemberian allopurinol. Tentunya keadaan ini memerlukan pemantauan yang ketat, sehingga kita tahu kapan hidrasi dihentikan dan kapan sitostatika dapat dimulai. Prognosis pasien leukemia limfositik akut dengan hiperleukositosis pada umumnya buruk.
\end{abstract}

Kata kunci: leukemia, hiperleukositosis, hiperurisemia, hiperkalemia,hiperfosfatemia, hipokalsemia, asidosis laktat

$\mathcal{H}$ iperleukositosis merupakan salah satu kegawatan onkologi yang memerlukan penanganan segera. Meningkatnya morbiditas dan mortalitas pada pasien leukemia seringkali ditemukan pada keadaan hiperleukositosis. Apabila keadaan ini tidak ditangani dengan tepat dan segera dapat menimbulkan kematian akibat perdarahan intrakranial dan atau pulmonal, serta gangguan metabolik karena lisisnya sel leukemia.,4

Makalah ini akan membahas evaluasi pasien LLA dengan hiperleukositosis di Bagian IKA FKUI/RSCM, Jakarta.

Dr. Caroline Mulawi. Peserta Program studi Ilmu Kesehatan Anak FKUIRSCM.

Alamat Korespondensi:

Dr. Endang Windyastuti $\mathrm{SpA}(\mathrm{K})$

Staf Subbagian Hematologi. Bagian Ilmu Kesehatan Anak FKUI-RSCM.

Jl. Salemba no.6, Jakarta 10430.

Telepon: 021-31901170.

\section{Hiperleukositosis}

Hiperleukositosis adalah peningkatan jumlah sel leukosit darah tepi melebihi 100 000/ul., ${ }^{1,2}$ Peningkatan berlebihan sel leukosit ini terjadi akibat gangguan pengaturan pelepasan sel leukosit dari sumsum tulang sehingga leukosit yang beredar dalam sirkulasi berlebihan. $^{2}$

Hiperleukositosis dapat ditemukan pada 6-15\% pasien leukemia limfositik akut (LLA), 13-22\% pasien leukemia non-limfositik akut dan pada hampir semua pasien mielogenus kronis. Di Bagian IKA FKUI/ RSCM Jakarta dalam kurun waktu Mei 1994 Desember 2000 terdapat 57 (22\%) pasien dengan hiperleukositosis dari 262 pasien LLA. Sebagian besar pasien berusia antara 2-9 tahun dan $61 \%$ datang pertama kali dengan jumlah leukosit $>100.000 / u l$ (Tabel 1).

Hiperleukositosis dapat menyebabkan viskositas darah meningkat, terjadi agregasi serta trombus sel blas pada mikrosirkulasi. Selain itu akibat ukuran sel blas 
Tabel 1. Karakteristik klinis pasien LLA dengan hiperleukositosis di Bagian IKA FKUI-RSCM (1994-2000)

\begin{tabular}{llc}
\hline Parameter & & Jumlah \\
\hline Jenis kelamin & Laki-laki & 36 \\
& Perempuan & 21 \\
Usia (tahun) & $<1$ & 2 \\
& $1-2$ & 6 \\
& $2-9$ & 35 \\
& $>10$ & 14 \\
Jumlah leukosit (x103/ul) & $>50-100$ & 22 \\
& $>100-200$ & 28 \\
& $>200$ & 7 \\
\hline
\end{tabular}

yang lebih besar dibanding sel leukosit matur, serta tidak mudah berubah bentuk menyebabkan sel blas akan mudah terperangkap dan menimbulkan oklusi pada mikrosirkulasi. Keadaan ini disebut dengan leukostasis. ${ }^{1,3}$

Organ tubuh yang paling sering mengalami leukostasis adalah susunan saraf pusat dan paru. Leukostasis akan menyebabkan perfusi yang buruk dan terjadi hipoksia, metabolisme anaerob, asidosis laktat, akhirnya akan menimbulkan kerusakan dinding pembuluh darah dan perdarahan. Bila leukostasis terjadi pada susunan saraf pusat maka akan terdapat gejala klinis berupa pusing, penglihatan kabur, tinitus, ataksia, delirium, perdarahan retina dan perdarahan intra kranial. ${ }^{4-6}$

Gejala klinis yang berhubungan dengan lekostasis pada paru ialah takipne, dispne, hipoksia dan gagal nafas. Pada Tabel 1 terlihat gejala klinis pada 57 pasien dengan hiperleukositosis, lebih dari $80 \%$ datang dengan hepatomegali dan splenomegali, sedang gejala

Tabel 2. Gejala klinis pasien LLA dengan hiperleukositosis Di Bag IKA FKUI/RSCM, Jakarta (1994-2000)

\begin{tabular}{lccc}
\hline \multirow{2}{*}{ Gejala } & \multicolumn{3}{c}{ Jumlah Leukosit $(\mathrm{x} 103 / \mathrm{ul})$} \\
\cline { 2 - 4 } \multicolumn{1}{c}{ Klinis } & $50-100$ & $>100-200$ & $>200$ \\
\hline Hepatomegali & 18 & 23 & 6 \\
Splenomegali & 18 & 26 & 6 \\
Adenopati & 10 & 10 & 4 \\
Delirium & 0 & 2 & 0 \\
Mata kabur & 2 & 5 & 4 \\
Hipoksia & 7 & 7 & 6 \\
Sesak nafas & 13 & 20 & 7 \\
\hline Jumlah pasien & 22 & 28 & 7 \\
\hline
\end{tabular}

lekostasis yang ditemukan adalah delirium, penglihatan kabur, hipoksia dan sesak nafas.

Penghancuran sel abnormal berlebihan pada keadaan hiperleukositosis bisa berlangsung secara spontan atau setelah terapi sitostatika. Pada keadaan ini harus dipantau terjadinya sindrom lisis tumor yang dapat mengakibatkan gangguan metabolik dan gagal ginjal akut. ${ }^{7,8}$

\section{Sindrom Lisis Tumor pada Hiperleu- kositosis}

Gangguan metabolik yang sering ditemukan pada keadaan sindrom lisis tumor adalah hiperurisemia, hiperkalemia, hiperfosfatemia dan hipokalsemia, tetapi dapat juga terjadi asidosis laktat dan azotemia. ${ }^{7,8}$

Gangguan metabolik biasanya terjadi pada sindrom lisis tumor dan seringkali ditemukan pada pasien limfoma non-Hodgin dan leukemia limfositik akut. ${ }^{7}$ Derajat metabolik yang terjadi pada sindrom lisis tumor dipengaruhi oleh saat awal pengobatan kemoterapi dan intensitasnya, jumlah ion intraselular yang keluar, hidrasi yang adekuat, status asam basa dan laju filtrasi glomerulus. ${ }^{6,8}$ Sindrom lisis tumor dapat terjadi secara spontan, yaitu sebelum kemoterapi dimulai atau sampai 5 hari setelah kemoterapi diberikan. ${ }^{79}$ Lisis sel tumor menyebabkan terjadinya pelepasan kalium secara cepat, asam urat yang berasal dari asam nukleat dan fosfat intraselular ke ekstraselular. Dengan demikian terjadilah keadaan hiperkalemia, hiperurisemia, hiperfosfatemia dengan hipokalsemia sekunder. $^{7-9}$

\section{Hiperurikemia}

Hiperurikemia dapat timbul secara spontan atau sebagai komplikasi dari perusakan cepat dari sel tumor akibat kemoterapi. Keadaan ini ditandai dengan peningkatan kadar asam urat darah melebihi $7 \mathrm{mg} /$ dl dan dapat mencapai $20 \mathrm{mg} / \mathrm{dl}$ bahkan lebih. ${ }^{5}$ Asam urat merupakan hasil akhir metabolisme purin dan diekskresi oleh ginjal. Di dalam hati, xantin dan hipoxantin dikatalisisasi oleh xantin oksidase menjadi asam urat. Sebanyak kira-kira $98 \%$ asam urat terionisasi pada keadaan asam-basa fisiologis ( $\mathrm{pK}$ asam urat 5,6). ${ }^{10}$ Daya larut asam urat sangat buruk pada keadaan urin yang bersifat asam namun relatif larut di dalam plasma. Jika kapabilitas ekskresi ginjal terlampaui, akan terjadi nefropati asam urat. ${ }^{\text {? }}$ 
Insufisiensi ginjal timbul pada saat terjadi supersaturasi urin oleh asam urat dan kristal asam urat pada tubulus renal dan duktus koligentes distal. Batu asam urat dapat berkembang pada kurang dari $10 \%$ kasus. $^{7}$ Meskipun hiperurikemia merupakan gejala klinis yang paling penting pada sindrom lisis tumor yang dapat berkembang menjadi gagal ginjal akut, beberapa pasien tidak mengalami hiperurikemia ini. ${ }^{8,11}$ Penyebab lain yang berpotensi untuk terjadi insufisiensi ginjal di antaranya adalah hiperfosfatemia dan xantinuria. ${ }^{6}$ Di Subbagian Hematologi Anak antara tahun 1994-2000, di antara 57 pasien leukemia limfositik akut dengan hiperleukositosis, didapatkan hiperurikemia pada 22 pasien (38\%). Duapuluh lima $(43,8 \%)$ di antaranya mengalami insufisiensi ginjal dan 1 pasien dengan gagal ginjal kronis pada kadar asam urat $14,5 \mathrm{mg} / \mathrm{dl} .^{7}$ (Tabel 3)

Tabel 3. Gangguan metabolisme akibat Sindrom lisis tumor pada pasien LLA dengan hiperleukositosis, Bag IKA FKUI/ RSCM 1994-2000

\begin{tabular}{lcc}
\hline Gangguan & \multicolumn{2}{c}{ Jumlah Leukosit $(\mathrm{x} 103 / \mathrm{ul})$} \\
\cline { 2 - 3 } metabolisme & $<100$ & $>100$ \\
\hline Hiperurikemia & 10 & 12 \\
Hiperfosfatemia & 1 & 0 \\
Hiperkalemia & 0 & 1 \\
Asidosis laktat & 9 & 26 \\
Insufisiensi ginjal & 8 & 17 \\
\hline Jumlah pasien & 22 & 35 \\
\hline
\end{tabular}

He, dkk dalam penelitian pada tahun 1999 mendapatkan 4 kasus leukemia limfoblastik akut yang mengalami sindrom lisis tumor setelah diberikan kemoterapi. Tiga di antaranya terjadi gangguan fungsi ginjal dan satu orang lainnya meninggal karena gagal ginjal akut. ${ }^{12}$

Gejala yang tampak biasanya asimptomatis sampai terjadi oliguria atau anuria. Artritis akut kadang-kadang dapat ditemukan pada pasien leukemia. ${ }^{5}$ Gejala mual, muntah dan letargi pada umumnya timbul pada kadar asam urat $10-15 \mathrm{mg} / \mathrm{dl}^{7}$ Beberapa pasien mengeluh nyeri pinggang atau hematuria, dan pada analisis urin ditemukan banyak kristal asam urat. Namun apabila tidak ditemukan kristal asam urat pada urin pasien, bukan tidak mungkin sudah terjadi hiperurisemia, karena kristaluria dan hematuria hanya timbul selama fase akut. Kadar ureum dan kreatinin darah dapat meningkat. ${ }^{9}$

\section{Hiperkalemia}

Hiperkalemia ringan-sedang ditandai dengan kadar kalium serum melebihi 5,5 meq/L, dan hiperkalemia berat apabila ditemukan kadar kalium serum melebihi $6 \mathrm{meq} / \mathrm{L}$ dan atau telah terjadi perubahan pada elektrokardiogram (EKG).2 Hiperkalemia terjadi akibat pelepasan kalium intrasel. ${ }^{2,7}$ Pada keadaan berat dapat terjadi aritmia jantung seperti asistol, takikardi ventrikular atau fibrilasi, dan henti jantung. Manifestasi lain adalah gangguan neuromuskular seperti kelemahan otot, parestesia, spasme otot dan paralisis flaksid asenden. Nausea, muntah, diare dan anoreksia juga dapat timbul. ${ }^{9}$ Gambaran EKG pada kadar kalium serum melebihi 7 meq/L berupa gelombang $T$ yang tinggi dan pelebaran QRS. ${ }^{7}$

\section{Hiperfosfatemia dan hipokalsemia}

Hiperfosfatemia merupakan komplikasi metabolik lain yang berhubungan dengan sindrom tumor lisis. Hipokalsemia biasanya menyertai keadaan hiperfosfatemia ini yang dapat menyebabkan terjadinya resorpsi tulang dan terjadi pembentukan kompleks kalsiumfosfat. Kompleks ini dapat mengganggu parenkim ginjal atau duktus koligentes, dan pada akhirnya dapat terjadi insufisiensi ginjal sampai gagal ginjal akut., ${ }^{9,11}$ Deposisi kompleks kalsium-fosfat pada jaringan dapat menyebabkan timbulnya pruritus, iritis dan artritis. Manifestasi hipokalsemia dapat berupa spasme karpopedal, tetani, kejang dan pada kasus yang ekstrim dapat terjadi henti jantung. ${ }^{7}$

\section{Asidosis laktat}

Asidosis laktat dapat dijumpai pada pasien leukemia akut dengan hiperleukositosis. Hal ini terjadi karena adanya peningkatan glikogenolisis pada jaringan perifer dan klirens laktat dan piruvat pada hepar yang tidak sempurna. Akibatnya terjadi hipoksia jaringan dan asidosis metabolik. ${ }^{2,4,5}$ Dari kasus leukemia limfositik akut di RSCM antara tahun 1994-2000, sebanyak 46\% dengan hiperleukositosis terjadi asidosis metabolik. ${ }^{7}$

\section{Tata laksana}

Mengingat terjadinya gangguan metabolik pada pasien leukemia dengan hiperleukositosis dapat berakibat 
fatal, maka intervensi dini dan adekuat harus segera dilakukan untuk menurunkan jumlah leukosit. Bila dijumpai keadaan hiperleukositosis, maka harus segera dilakukan tindakan yang meliputi hidrasi yang agresif, alkalinisasi urin dan pemberian allopurinol. . $^{1,9,12}$

Hidrasi dilakukan dengan cairan parenteral glukosa 5\% dalam 0,225\% normal salin, sebanyak 2-3 kali kebutuhan cairan rumatan atau $2-3$ liter $/ \mathrm{m} 2 /$ hari untuk mendapatkan diuresis minimal $3 \mathrm{cc} / \mathrm{kg} / \mathrm{hari} .{ }^{5711}$ Alkalinisasi urin dilakukan dengan menambahkan sodium bikarbonat ke dalam cairan parenteral sebanyak 40-60 meq/L untuk mempertahankan $\mathrm{pH}$ urin antara $7,0-7,5 .^{2}$ Dengan kenaikkan $\mathrm{pH}$ urin tersebut menyebabkan asam urat terionisasi sehingga mencegah pembentukan kristal asam urat. Namun bila terjadi alkalinisasi yang berlebihan, dapat menyebabkan deposisi kompleks kalsium-fosfat yang kemudian akan terjadi penurunan laju filtrasi glomerulus. Oleh karena itu perlu dilakukan pemantauan ketat $\mathrm{pH}$ urin., ${ }^{8,10}$ Pemberian allopurinol dengan dosis $200-300 \mathrm{mg} / \mathrm{m} 2 /$ hari atau $10 \mathrm{mg} / \mathrm{kgBB} /$ hari ditujukan untuk menurunkan konsentrasi asam urat plasma.2 Obat ini diberikan sampai didapatkan $\mathrm{pH}$ urin mencapai sekitar $7,5.4,6,9$

Allopurinol sebagai analog hipoxantin, bekerja dengan cara mengurangi konsentrasi asam urat dengan menginhibisi xantin oksidase, sehingga konversi dari hipoxantin dan xantin menjadi asam urat tidak terjadi. ${ }^{11}$ Urikolitik yang lain adalah enzim urat oksidase, yang dapat mengubah asam urat menjadi alantoin. Dikatakan bahwa alantoin ini adalah metabolit yang 5-10 kali lebih larut dibanding asam urat. Pui, dkk dan Goldman, dkk lebih menganjurkan penggunaan urat oksidase rekombinan untuk mengobati hiperurisemia yang berat pada kasus leukemia akut di Amerika dibanding bentuk nonrekombinan yang dapat menyebabkan gejala hipersensitivitas. ${ }^{13,14}$ Di lain pihak, Patte, dkk dalam penelitiannya mendapatkan kejadian gangguan metabolik pada pasien leukemia menurun setelah pemmberian urat oksidase bentuk non-rekombinan dan kejadian anafilaksis yang ditemukan sangat rendah. ${ }^{15}$ Jika dengan allopurinol keadaan hiperurikemia tidak dapat dicegah, keadaan ini akan berkembang menjadi oliguria atau anuria. Bila dengan hidrasi tambahan dan pemberian furosemid tidak membantu, maka dipikirkan untuk dilakukan hemodialisis. ${ }^{5,6}$

Menurunkan kalium serum dapat dengan me- makai cation exchange resin untuk mengikat kalium. Selain itu dapat digunakan antagonis kalsium glukonas. Pemberian sodium bikarbonat untuk mengoreksi asidosis laktat dapat menyebabkan perpindahan kalium ke dalam sel. Dekstrosa hipertonik dan insulin juga dapat digunakan untuk menurunkan kadar kalium serum. ${ }^{9}$ Untuk menurunkan kadar fosfat dapat digunakan aluminium hidroksida, selain itu dapat juga dipakai dekstrosa hipertonik dan insulin. Dengan mengoreksi hiperfosfatemia secara tidak langsung juga akan memperbaiki keadaan hipokalsemia. ${ }^{9,11}$

Sitostatik diberikan secara bertahap. Pada leukemia limfositik akut, beberapa ahli menganjurkan pemberian kortikosteroid dosis rendah untuk mereduksi leukosit setelah hidrasi, alkalinisasi dan pemberian allopurinol dimulai. ${ }^{5}$

\section{Prognosis}

Pasien LLA dengan hiperleukositosis termasuk dalam golongan risiko tinggi sehingga prognosis lebih buruk dibandingkan dengan mereka yang mempunyai jumlah leukosit <50 000/ul. ${ }^{1,6,16}$ Selain prognosis dipengaruhi oleh jumlah leukosit, ada beberapa faktor lain yang juga berperan seperti usia, fenotip, sitogenetik dan respons terhadap pemberian prednison.17 Morbiditas dan mortalitas lebih tinggi pada pasien dengan leukosit $>50.000 /$ ul dan sebagai penyebab kematian yang terjadi pada fase induksi kemoterapi umumnya oleh karena sepsis dan perdarahan hebat. ${ }^{6,17}$

Di Bagian IKA FKUI/RSCM, diantara 22 kasus LLA, remisi dicapai pada 44 (77\%), dan $13(22,8 \%)$ pasien dengan hiperleukositosis meninggal pada fase induksi (Tabel 4). Kesintasan 5 tahun (5 years overall survival rate) pasien LLA dengan hiperleukositosis di negara maju sebesar 70\%, $, 16,17$ sedang di Bagian IKA FKUI/RSCM sebesar 57,8\%. Perbedaan ini mungkin disebabkan karena adanya variasi biologik, perbedaan protokol pengobatan dan adalah kualitas perawatan penunjang.

\section{Kesimpulan}

Hiperleukositosis, sebagai salah satu kegawatan onkologi dapat memberikan dampak yang merugikan kepada pasien leukemia akibat komplikasi yang ditimbulkan. Salah satunya adalah gangguan metabolik 
Tabel 4. Outcome pasien LLA dengan hiperleukositosis di Bagian IKA FKUI/RSCM (1994-2000)

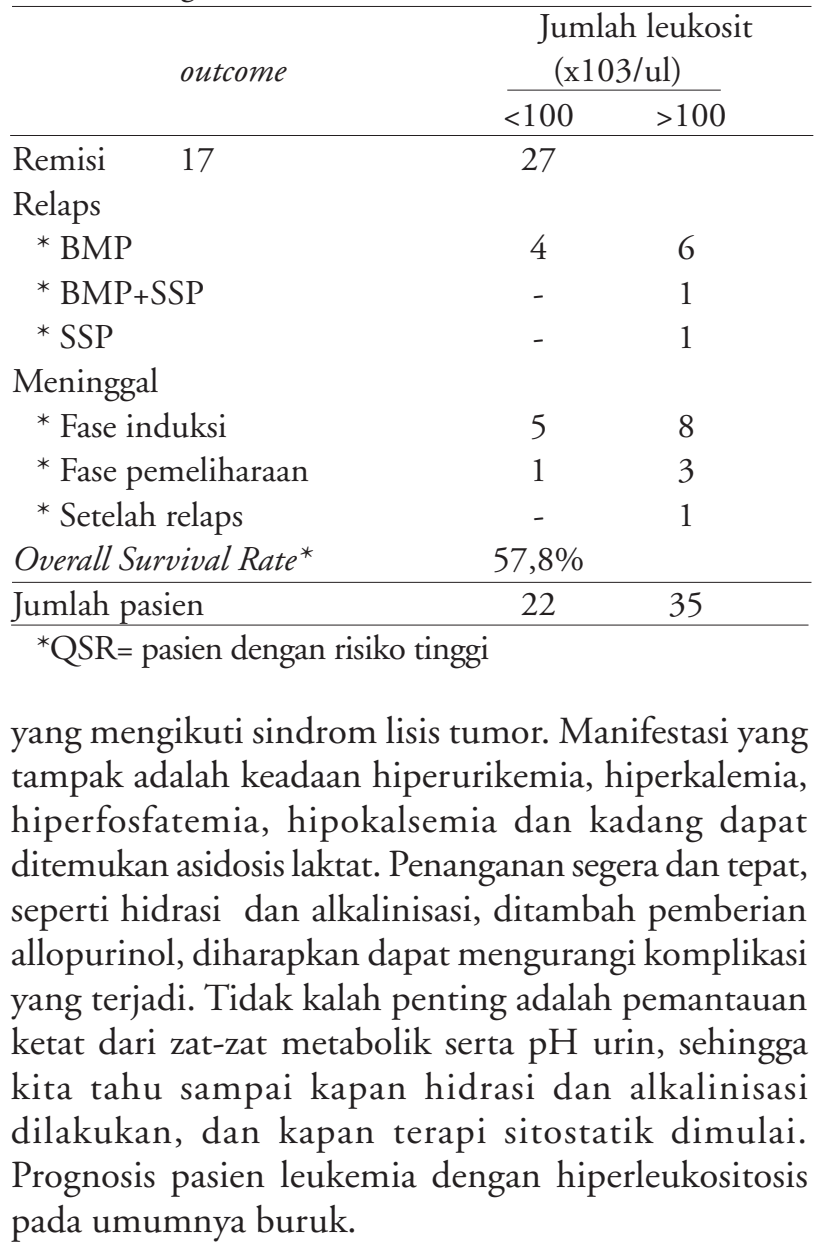

\section{Daftar Pustaka}

1. Niemeyer CM, Sallan SE. Acute lymphoblastic leukemia. Dalam: Nathan D, Oski F, penyunting. Hematology of infancy and childhood. Edisi ke-4. Philadelphia: WB Saunders; 1993. h. 1249-74.

2. Taylor DS. Oncologic emergencies. eMedicine J 2002 March; 3(3). Didapat dari: URL: http//www.eMedicine journal.htm.

3. Inoue S. Leukocytosis. eMedicine J 2002 Jan; 3(1). Didapat dari: URL: http//www.eMedicine journal.htm.
4. Sinniah D, Bunin NJ. Hyperleukocytosis. Dalam: D'angio GJ, Sinniah D, Meadow AT, Evans AE, Pritchard J, penyunting. Practical Pediatric Oncology,ed. New York:Wiley-Liss, 1992. h. 37-39

5. Ludwig H, Fritz E. Oncological emergencies. Dalam: Cavalli F, Hansen H, penyunting. Textbook of medical oncology. London: Martin Dunitz Ltd; 1997. h. 395-418.

6. Lange B, O’Neill JA, Goldwein JW, Packer RJ, Ross III AJ. Oncologic emergencies. Dalam: Pizzo PA, Poplack DG, penyunting. Principles and Practices of Pediatric Oncology. Edisi ke-3, Philadelphia: Lippincott-Raven; 1997. h. 761-798

7. Sarnaik AP, Grupp SA, Konop R, Bergstrom SK, Chan H, Coppes MJ. Tumor lysis syndrome. Medicine J 2001; 2 (9). Didapat dari: URL: http//www.tumor lysis syndrome from pediatric oncology.htm.

8. Jones DP, Mahmoud H, Chesney RW. Tumor lysis syndrome: pathogenesis and management. Pediatr Nephrol 1995; 9:206-12.

9. Jeha S. Tumor lysis syndrome. Semin Hematol 2001; 38:4-8.

10. Pui CH. Introduction-optimal treatment of malignancies associated with hyperuricemia. Semin Hematol 2001; 38:1-3.

11. Wetzstein GA. Tumor lysis syndrome: a treatment guide. Oncology special ed 2001; 4:123-6.

12. He H, Li C, Han M. Acute lymphoblastic leukemia complicated with tumor lysis syndrome-four cases report. Zhonghua Xue Ye Xue Za Zhi 1999; 20:310-2. Abstrak.

13. Pui CH. Urate oxidase in the prophylaxis or treatment of hyperuricemia: the United States experience. Semin Hematol 2001; 38:21-4.

14. Goldman SC, Holcenberg JS, Finklestein JZ, dkk. A randomized comparison between rasburicase and allopurinol in children with lymphoma or leukemia at high risk for tumor lysis. Blood 2001; 97:2998-3003. Abstrak.

15. Patte C, Sakiroglu O, Sommelet D. European experience in the treatment of hyperuricemia. Semin Hematol 2001; 38:9-12.

16. Schrappe M, Ruter A, Ludwig W-D, Harbott J, Zimmermann M, Hiddemann W, Niemeyer C et al. Improved uotcome in childhood acute lymphoblastic leukemia despite reduced use of anthracycline and cranial radiotherapy: results of trial ALL-BFM 90. Blood 2000; 95:3310-22.

17. Ishii E, Eguchi H, Matsuzaki A, Koga H, Yanai F, Kuroda $\mathrm{H}$ dkk. Outcome of Acute lymphoblastic leukemia in children with Al 90 Regimen. Impact of response to treatment and sex difference on prognosis factor. Med Ped Oncol 2002; 37:10-19. 